\title{
Effect of Seed Hardening with Micronutrients and Botanicals on Seed Quality Parameters in Chickpea (Cicer arietinum L.)
}

\author{
B. Saicharan*, Bineeta M. Bara, Prashant Kumar Rai, B. Nihar and R. Pramod \\ Department of Genetics and Plant Breeding, Sam Higginbottom University of Agriculture, \\ Technology and Sciences, Prayagraj, UP-211007, India
}

*Corresponding author

\begin{abstract}
A B S T R A C T
Keywords

Chickpea, Seed Hardening, Micronutrients, Botanicals and seed quality

\section{Article Info}

Accepted:

04 August 2019

Available Online:

10 September 2019

An investigation was carried out to study the effect of seed hardening with micronutrients and botanicals on seed quality parameters in chickpea. The chickpea cv. PUSA-362 was imposed to various seed hardening treatments viz., Neem leaf extract @ 5\%, Tulsi leaf extract@5\%, Papaya leaf extract@5\%, Moringaleaf extract@5\%, $\mathrm{CaCl}_{2} @ 1 \%$ and 2\%, $\mathrm{KCl} @ 1 \%$ and $2 \%, \mathrm{KNO}_{3} @ 1 \%$ and 2\%, $\mathrm{KH}_{2} \mathrm{PO}_{4} @ 1 \%$ and 2\%. The above treated seeds along with control for their seed quality parameters. The study revealed that seed hardening with $\mathrm{KH}_{2} \mathrm{PO}_{4} @ 2 \%$ in micronutrients and Neem leaf extract @ 5\% in botanicals showed better performance in maximum seed quality parameters as compared to other treatments and control on the basis of lab studies.

\section{Introduction}

Pulses are the wonderful gift of nature plays an important role in both Indian economy and diet (Jat et al., 2012). Among the pulses chickpea (Cicer arietinum L.) is having vital role in the diet of rural and urban masses. Chickpea is important food legume $\mathrm{s}$ for production worldwide. It is one of the most extensively grown rabi pulse crop in India.

Chickpea is the third most important pulse crop in the world, after dry beans and peas, produced in the world (Anon., 2011) chickpea

occupies a prime position among the pulses in the country with a maximum hectarage, production and its high nutritive value. It is known to have originated in western Asia. Chickpea is a member of the legume, pea, or pulse family "Fabaceae". Among annual seed crops, it ranks $14^{\text {th }}$ in terms of area and $16^{\text {th }}$ in production. Chickpeas have an ancient history, and were one of the earliest cultivate vegetables. Remains from 7500 years ago have been found in the Middle East (Philologos, 2007). Chickpea is widely grown across the country and serves as a multipurpose crop (Shiferaw et al., 2007).
\end{abstract}


First, it fixes atmospheric nitrogen in soils and thus improves soil fertility and saves fertilizer costs in subsequent crops. Secondly, it improves more intensive and productive use of land, particularly in areas where land is scarce and the crop can be grown as a second crop using residual moisture. Thirdly, it reduces malnutrition and improves human health especially for the poor who cannot afford livestock products. It is an excellent source of protein, fiber, complex carbohydrates, vitamins and minerals.

Seed hardening is a technique which has been used successfully for vigour enhancement in several seeds like rice, wheat (Basra et al., 2003, 2004); Lee and Kim, 2000. In this technique, seeds may imposed to different conditions like alternate wetting an drying, chilling treatment or high temperature for different durations (Farooq et al., 2005). Several researchers worked on hardening and other techniques for increasing in vigour of seeds and found hardening better than other. Hence the study was undertaken in chickpea cv. PUSA-362 with an objective to study the effect of seed hardening with micronutrients and botanicals on seed quality parameters in chickpea.

\section{Materials and Methods}

The present investigation was done in the Post graduate laboratory of seed science and technology, Department of Genetics and Plant Breeding, Sam Higginbottom University of Agriculture, Technology and Sciences. The experiment consisted of thirteen treatments including control viz., $\mathrm{T}_{0}$ : Control, $\mathrm{T}_{1}$ : Neemleaf extract@5\%, T : Tulsileaf extract @ 5\%, $\mathrm{T}_{3}$ : Papayaleaf extract@ 5\%, T4: Moringaleaf extract@5\%,T5: $\mathrm{CaCl}_{2} @ 1 \%$, $\mathrm{T}_{6}: \mathrm{CaCl}_{2} @ 2 \%, \mathrm{~T}_{7}: \mathrm{KCl} @ 1 \%, \mathrm{~T}_{8}: \mathrm{KCL} @$ $2 \%, \mathrm{~T}_{9}: \mathrm{KNo}_{3} @ 1 \%, \mathrm{~T}_{10}: \mathrm{KNo}_{3} @ 2 \%, \mathrm{~T}_{11}$ : $\mathrm{KH}_{2} \mathrm{PO}_{4} @ 1 \%, \mathrm{~T}_{12}: \mathrm{KH}_{2} \mathrm{PO}_{4} @ 2 \%$. The seeds were soaked in the required solutions for
12 hours at temperature $25^{\circ} \mathrm{C}$. After 12 hours of soaking the solution drained out and presoaked seeds were shade dried to obtain its original weight. A trail was laid out with about thirteen treatments adopting completely randomized design with four replications under controlled lab condition.

The observations on germination percentage (ISTA, 2001), root length, shoot length, seedling length, seedling fresh weight, seedling dry weight, vigour index I and vigour index II (Abdul-Baki and Anderson, 1973) were recorded in this experiment. The experimental data were subjected to analysis of Analysis of variance, mean, standard error and critical difference (Bradley and Christopher, 2009).

\section{Results and Discussion}

According to the results, all studied traits were affected by the treatments and there was completely significant difference between control (unhardened seeds) and hardened seeds (Tables 1 and 2). Seed hardening means alternating drying and wetting of seeds (Pen aloza and Eira, 1993).

The mean performance of germination percentage ranged from 84.0 to $96.0 \%$ with the mean value $90.2 \%$. Significantly highest germination percentage in micronutrients was reported in the treatment $\mathrm{T}_{6}: \mathrm{CaCl}_{2} @ 2 \%$ $(96.0 \%)$ and in botanicals, treatment $\mathrm{T}_{1}$ : Neem leaf extract@5\% (94.0\%) was recorded as higher germination percentage. The minimum germination percentage was recorded in the treatment $\mathrm{T}_{0}$ : Control $(84.0 \%)$.

The mean performance of root length ranged from 9.2 to $24.1 \mathrm{~cm}$ with the mean value 16.3 . The maximum root length in micronutrients was recorded in the treatment $\mathrm{T}_{12}: \mathrm{KH}_{2} \mathrm{PO}_{4} @$ $2 \%(24.1 \mathrm{~cm})$ and in botanicals, treatment $\mathrm{T}_{1}$ : Neem leaf extract@ 5 \% (21.3 cm) was 
recorded maximum root length. The minimum root length was recorded in the treatment $\mathrm{T}_{0}$ : Control $(9.2 \mathrm{~cm})$.

The mean performance of shoot length ranged from 6.3 to $14.4 \mathrm{~cm}$ with the mean value 10.4 $\mathrm{cm}$. The maximum shoot length in micronutrients was recorded in the treatment
$\mathrm{T}_{12}: \mathrm{KH}_{2} \mathrm{PO}_{4}$ @ $2 \% \quad(14.4 \mathrm{~cm})$ and in botanicals, treatment $\mathrm{T}_{1}$ : Neem leaf extract @ $5 \%(13.4 \mathrm{~cm})$ was recorded maximum shoot length. The minimum shoot was recorded in the treatment $\mathrm{T}_{0}$ : Control $(6.3 \mathrm{~cm})$. The mean performance of seedling length ranged from 15.5 to $38.5 \mathrm{~cm}$ with mean value $26.7 \mathrm{~cm}$.

Table.1 Analysis variance of seed quality parameters in chickpea cv. PUSA-362

\begin{tabular}{|c|c|c|c|}
\hline \multirow{2}{*}{ S. No. } & Characters & \multicolumn{2}{|c|}{ Mean sum of squares } \\
\cline { 2 - 4 } & & Treatments $(\mathbf{d f}=\mathbf{1 2})$ & Error $(\mathbf{d f}=\mathbf{3 9})$ \\
\hline $\mathbf{1 .}$ & Germination percentage & $63.90^{* *}$ & 3.74 \\
\hline $\mathbf{2 .}$ & Root length & $85.80^{* *}$ & 0.14 \\
\hline $\mathbf{3 .}$ & Shoot length & $34.02^{* *}$ & 0.04 \\
\hline $\mathbf{4 .}$ & Seedling length & $224.7 * *$ & 0.16 \\
\hline $\mathbf{5 .}$ & Seedling fresh weight & $11.92^{* *}$ & 0.13 \\
\hline $\mathbf{6 .}$ & Seedling dry weight & $5.63 * *$ & 0.05 \\
\hline $\mathbf{7 .}$ & Vigour index I & $2434462.4^{* *}$ & 3602.1 \\
\hline $\mathbf{8 .}$ & Vigour index II & $57185.2 * *$ & 473.2 \\
\hline
\end{tabular}

Table.2 Mean performance of 8 parameters of seed quality in chickpea cv. PUSA-362.

\begin{tabular}{|c|c|c|c|c|c|c|c|c|c|}
\hline $\begin{array}{l}\text { S. } \\
\text { No. }\end{array}$ & Treatments & $\begin{array}{c}\text { Germination } \\
(\%)\end{array}$ & $\begin{array}{c}\text { Root } \\
\text { length } \\
(\mathrm{cm})\end{array}$ & $\begin{array}{c}\text { Shoot } \\
\text { length } \\
(\mathrm{cm})\end{array}$ & $\begin{array}{l}\text { Seedling } \\
\text { length } \\
\text { (cm) }\end{array}$ & $\begin{array}{l}\text { Seedling } \\
\text { fresh } \\
\text { weight } \\
\text { (g) }\end{array}$ & $\begin{array}{l}\text { Seedling } \\
\text { dry } \\
\text { weight } \\
\text { (g) }\end{array}$ & $\begin{array}{l}\text { Vigour } \\
\text { index I }\end{array}$ & $\begin{array}{c}\text { Vigour } \\
\text { index II }\end{array}$ \\
\hline 1 & $\mathrm{~T}_{0}$ & 84 & 9.2 & 6.3 & 15.5 & 6.2 & 1.54 & 2080.4 & 129.0 \\
\hline 2 & $\mathrm{~T}_{1}$ & 94 & 21.3 & 13.4 & 34.7 & 10.4 & 4.67 & 3265.4 & 439.5 \\
\hline 3 & $\mathrm{~T}_{2}$ & 93 & 19.4 & 12.5 & 31.8 & 10.2 & 4.38 & 2961.0 & 407.4 \\
\hline 4 & $\mathrm{~T}_{3}$ & 85 & 10.6 & 6.8 & 17.4 & 6.8 & 1.95 & 1479.0 & 166.6 \\
\hline 5 & $\mathrm{~T}_{4}$ & 88 & 14.6 & 8.4 & 23.0 & 8.1 & 2.63 & 2019.9 & 231.6 \\
\hline 6 & $\mathrm{~T}_{5}$ & 91 & 15.2 & 9.0 & 24.2 & 8.6 & 3.37 & 2202.4 & 306.9 \\
\hline 7 & $\mathrm{~T}_{6}$ & 96 & 22.7 & 14.2 & 37.0 & 11.0 & 4.83 & 3547.4 & 463.5 \\
\hline 8 & $\mathrm{~T}_{7}$ & 86 & 13.2 & 8.0 & 21.2 & 7.6 & 2.34 & 1824.2 & 201.3 \\
\hline 9 & $\mathrm{~T}_{8}$ & 92 & 17.4 & 12.3 & 29.8 & 9.6 & 4.23 & 2739.3 & 389.2 \\
\hline 10 & $\mathrm{~T}_{9}$ & 86 & 11.5 & 7.2 & 18.7 & 7.3 & 2.18 & 1607.6 & 187.3 \\
\hline 11 & $\mathrm{~T}_{10}$ & 92 & 16.4 & 11.7 & 28.1 & 9.0 & 3.98 & 2586.6 & 366.3 \\
\hline 12 & $\mathrm{~T}_{11}$ & 90 & 16.1 & 10.8 & 26.8 & 8.8 & 3.70 & 2409.8 & 332.6 \\
\hline 13 & $\mathrm{~T}_{12}$ & 95 & 24.1 & 14.4 & 38.5 & 12.1 & 4.95 & 3659.0 & 470.4 \\
\hline \multicolumn{2}{|c|}{ Grand Mean } & 90.2 & 16.3 & 10.4 & 26.7 & 8.9 & 3.44 & 2490.9 & 314.7 \\
\hline \multicolumn{2}{|c|}{ C.D (5\%) } & 2.77 & 0.54 & 0.29 & 0.57 & 0.52 & 0.33 & 85.8 & 31.1 \\
\hline \multicolumn{2}{|r|}{ SE(m) } & 0.97 & 0.19 & 0.10 & 0.20 & 0.18 & 0.11 & 30.0 & 10.8 \\
\hline \multicolumn{2}{|r|}{ SE(d) } & 1.37 & 0.27 & 0.14 & 0.28 & 0.26 & 0.16 & 42.4 & 15.38 \\
\hline
\end{tabular}

The maximum seedling length was obtained in micronutrients in the treatment $T_{12}$ : 
$\mathrm{KH}_{2} \mathrm{PO}_{4} @ 2 \%(38.5 \mathrm{~cm})$ and in botanicals, treatment $\mathrm{T}_{1}$ : Neemleaf extract @ 5\% (34.7 $\mathrm{cm})$ was recorded maximum seedling length. The minimum seedling length was recorded in the treatment $\mathrm{T}_{0}$ : Control $(15.5 \mathrm{~cm})$.

The mean performance of seedling fresh weight ranged from 6.2 to $12.1 \mathrm{~g}$ with the mean value $8.9 \mathrm{~cm}$. The highest seedling fresh weight was in micronutrients was recorded in the treatment $\mathrm{T}_{12}: \mathrm{KH}_{2} \mathrm{PO}_{4} @ 2 \%(12.1 \mathrm{~g})$ and in botanicals, treatment $\mathrm{T}_{1}$ : Neem leaf extract@ 5\% (10.4 g) was recorded higher seedling fresh weight. The lowest seedling fresh weight was recorded in the treatment $T_{0}$ : Control (6.2 g).

The mean performance of seedling dry weight ranged from 1.54 to $4.95 \mathrm{~g}$ with the mean value $8.9 \mathrm{~g}$. The highest seedling dry weight in micronutrients was recorded in the treatment $\mathrm{T}_{12}: \mathrm{KH}_{2} \mathrm{PO}_{4} @ 2 \%(4.95 \mathrm{~g})$ and in botanicals, treatment $\mathrm{T}_{1}$ : Neem leaf extract@ 5\% (4.67 g) was recorded highest seedling dry weight. The lowest seedling dry weight was recorded in the treatment $\mathrm{T}_{0}$ : Control $(1.54 \mathrm{~g})$. The mean performance of vigour index I range from 1479.0 to 3659.0 with the mean value 2409.8 . The highest vigour index $\mathrm{I}$ in micronutrients was obtained by the treatment $\mathrm{T}_{12}: \mathrm{KH}_{2} \mathrm{PO}_{4} @ 2 \%$ (3659.0) and in botanicals, treatment $\mathrm{T}_{1}$ : Neemleaf extract @ $5 \%$ (3265.4) was obtained higher vigour index I. The lowest vigour index I was obtained in the treatment $\mathrm{T}_{4}$ : Moringa leaf extract@5\%(1479.0).

The mean performance of vigour index II ranged from 129.0 to 470.4 with the mean value 314.7. The higher vigour index II in micronutrients was obtained by the treatment $\mathrm{T}_{12}: \mathrm{KH}_{2} \mathrm{PO}_{4} @ 2 \%$ (470.4) and in botanicals, treatment $\mathrm{T}_{1}$ : Neem leaf extract@ 5\% (439.5) was obtained higher vigour index II. The lowest vigour index II was obtained in the treatment $\mathrm{T}_{0}$ : Control (129.0).
On the basis of present investigation, it can be concluded that the seed hardening treatment found effectiveness with $\mathrm{KH}_{2} \mathrm{PO}_{4} @ 2 \%$ in micronutrients and Neem Leaf extract @ 5\% in botanicals showed superior performance on seed quality parameters.

The study showed improvement in seed hardening treatment to the seed is simple easy and in expensive approach to enhance the seed performance and thereby agricultural productivity especially in dry land resources of poor farmers. This clearly indicates the mode of action differs for the micronutrients and botanicals.

\section{Acknowledgement}

Authors are thankful to Dr. Bineeta M.Bara, Assistant Professor, Department of Genetics and Plant Breeding, SHUATS, Prayagraj, (U.P.) for providing necessary facilities, encouragement and support.

\section{References}

Abdul Baki, A.A. and Anderson, J.D. (1973).Vigor determination in soybean by multiple criteria. Crop Science. 13: 630-633.

Anonymous, $\quad$ FAOSTAT (2011). http://faostat.fao.org/site/567/DesktopD efault.aspx. (Accessed 12th December 2011).

Basra SMA, Farooq, M. and Khaliq A. (2003). Comparative study of presowing seed enhancement treatments in fine rice (Oryza sativa L.).Pakistan Journal Life and Social Science. 1: 5-9.

Basra SMA, Farooq, M. and Tabassum, R. (2004). Physiological and biochemical aspects of seed vigor enhancement treatments in fine rice (Oryza sativa L.). Seed Science and Technology. 33: 21.

Bradley, and Christopher, J.N. (2009) Split 
designs; what, why and how. Journal of quality technology. 41(4).

Farooq, M., Basra, S.M.A., Ahmad, N. and Hafeez, K. (2005). Thermal Hardening: A New Seed Vigor Enhancement Tool in Rice. Journal of Integrative Plant Biology. 47: 187-193.

International Seed Testing Association (2001). International rules for seed testing rules 1996. Seed Science and Technology. 24.

Jat, N.R., Rana, B.S. and Jat, S.K. (2013). Estimation of losses due to pulse beetle in chickpea. The Bioscan, 8: 861-863.

Lee, S.S. and Kim, J.H. (2000). Total sugars, $\alpha$-amylase activity, and germination after priming of normal and aged rice seeds. Korean Journal of Crop Science. 45: $108-111$.

Pen Aloza A.P.S., Eira M.T.S. 1993. Hydration-dehydration treatments on tamato seeds (Lycopersicum esculentum Mill). Seed Science and Technology, 21, 309-316.

Philologos. 2007. Chickpeas, Forward Association. Retrieved August 2, 2008.

Shiferaw, B. and Hailemariam, T. (2007). Structure and functioning of chickpea markets in Ethiopia: Evidence based on analyses of value chains linking smallholders and markets. International Production Management System Working Paper 6, ILRI, Nairobi, Kenya. 55.

\section{How to cite this article:}

Saicharan, B., Bineeta M. Bara, Prashant Kumar Rai, B. Nihar and Pramod, R. 2019. Effect of Seed Hardening with Micronutrients and Botanicals on Seed Quality Parameters in Chickpea (Cicer arietinum L.). Int.J.Curr.Microbiol.App.Sci. 8(09): 109-113. doi: https://doi.org/10.20546/ijcmas.2019.809.015 